\title{
The Promise of Integrated English Curriculum: Teachers' and Head Teachers' Reactions and Reflections
}

\author{
Charles M. Magoma \\ Department of Educational Management, Policy and Curriculum Studies, Kenyatta University, Kenya
}

Copyright $\bigcirc 2016$ by authors, all rights reserved. Authors agree that this article remains permanently open access under the terms of the Creative Commons Attribution License 4.0 International License

\begin{abstract}
The current Kenyan secondary English curriculum (2002) has adopted an integrated approach not only to teaching, but also to the assessment of English language and Literature. This re-organisation is meant to improve the standards of teaching and performance in English. However, national performance in integrated English has remained consistently below average, contrary to expectations. This paper is based on a research that was conducted in Nairobi North sub-county, Nairobi County, Kenya on The Promise of Integrated English: Teachers' and Head teachers' Reactions and Reflections. The study mainly used a qualitative approach and employed questionnaires, interview and observation schedules to collect data from 101 teachers of integrated English and 20 head teachers. Further, the heads of English at Kenya Institute of Curriculum Development, Directorate of Quality Assurance and Standards and Kenya National Examinations Council were interviewed. Raw data collected from questionnaires, interview and observation schedules were organized into significant patterns so as to easily interpret and understand the essence of the data. The study revealed that despite the promise of the re-organized English curriculum, teachers were teaching the integrated English curriculum without proper understanding of the methodology involved. Consequently, they faced difficulties and resorted to teaching English language and Literature as two separate subjects. The study concluded that there has been no effective implementation of integrated English curriculum in Nairobi North sub-county as was/is intended by the curriculum developers. The study recommends proper and continuing professional support to the teachers of integrated English curriculum in the form of in-service training for the promise to hold.
\end{abstract}

Keywords Curriculum, Integration, Integrated Approach, Integrated Curriculum, Integrated English Curriculum, Curriculum Implementation, Teacher Reflections

\section{Introduction}

The current secondary English curriculum (2002), in its re-organized form, has adopted an integrated approach not only to teaching, but also to the assessment of English language and Literature (Kenya Institute of Education - KIE) [1]).This re-organization is meant to improve the standards of teaching and performance in English (Ministry of Education - MoE) [2]; KIE [1]). At this point, it is important to note that performance in integrated English has been consistently below average, contrary to expectations, at both the national and provincial levels since 1989 when the first 8-4-4 examinations were conducted. The national mean percentage marks range between $24.15 \%$ and $42.74 \%$ between 1989 and 2012.

The Ministry of Education [2] points out that integration is based on the premise that good masterly of language enhances effective appreciation of literary material. On the other hand, it points out that literary material provides a natural context for teaching of language. This means that the methods used in the teaching/learning and assessment of English language and literature should facilitate integration. The teacher should, therefore, endeavour to understand the integrated approach.

According to the Kenya National Examinations Council (KNEC) [3], major changes have been introduced in secondary English examination format. It now adopts an integrated approach, where English language is tested together with Literature. Previously, the two were tested separately, with language being tested in papers One and Two; and Literature in Paper Three. In the new format, English Paper One examines functional skills- application of language in daily life; while Paper Two contains comprehension, literary appreciation and grammar. Paper Three assesses writing through creative composition and composition based on set Literature books. 
Table 1. Level of Difficulty to Implement Integrated English Curriculum

\begin{tabular}{|c|c|c|c|c|}
\hline \multirow{2}{*}{ Response } & \multicolumn{2}{|c|}{ Head Teachers } & \multicolumn{2}{|c|}{ Teachers } \\
\cline { 2 - 5 } & Frequency & Per cent & Frequency & Per cent \\
\hline Integrated English is difficult to implement. & 16 & 80.0 & 56 & 55.5 \\
\hline Integrated English is not difficult to implement. & 4 & 20.0 & 45 & 44.5 \\
\hline Total & 20 & 100.0 & 101 & 100.0 \\
\hline
\end{tabular}

\section{Research Methods}

The study mainly used a qualitative approach to get the teachers' and principals' reactions and reflections as regards the promise of integrated English. Basic quantitative techniques such as frequencies and percentages were used to analyse some of the data that were obtained. This study employed questionnaire, interview and observation instruments to collect data from 101 teachers of integrated English and 20 head teachers.

\section{Results and Discussion}

Teachers' and Head teachers' Reactions towards Integrated English Curriculum

Teachers' reactions towards secondary integrated English curriculum were sought through the use of a questionnaire structured into five areas: Level of difficulty of integrated English curriculum, teachers' attitudes towards secondary integrated English curriculum, need to integrate English language and Literature, integrated English curriculum and learners' needs and objectives of secondary integrated curriculum.

\section{i) Level of Difficulty of Integrated English Curriculum}

Teachers' responses in regard to the level of difficulty of the integrated English curriculum were sought and are presented in Table 1.

Table 1 shows that $55.5 \%$ of the teachers (56 teachers) indicated that it was difficult to implement secondary integrated English curriculum while $44.5 \%$ of them (45 teachers) said that it was not difficult to implement. One of the teachers who found it easy to implement integrated English curriculum said:

I have been fully trained to implement the integrated English curriculum. Thus, I am fully equipped to implement it. The several years of experience makes it even much easier for me each subsequent year.

Eighty per cent of the head teachers (16 head teachers) said that integrated English was difficult to implement and $20 \%$ of them (4 head teachers) indicated that the subject was not difficult to implement.

The fact that $44.6 \%$ of the teachers ( 45 teachers) and $80 \%$ of the head teachers (16 head teachers) said that integrated English was difficult to implement, it means that a substantial number of teachers faced difficulties when implementing integrated English curriculum. This could be the reason as to why in $80 \%$ of the lessons that were observed (64 classroom lesson observations), the concerned teachers taught English language and Literature as separate entities. They did not exploit the complementary relationship between the two subjects to teach the integrated English curriculum.

Lack of adequate teaching/learning resources was quoted by $62 \%$ of the teachers (32 teachers) and $50 \%$ of the head teachers (10 head teachers) as a reason working against easy implementation of integrated English curriculum. English language textbooks and Literature set-books were among the resources that were said by teachers to be inadequate. It was pointed out that in some of the schools, resources and facilities were not available and thus, that negatively affected the implementation of the subject. The researcher, from his classroom observations, noted that in most lessons nearly half of the students did not have the necessary learning materials such as English textbooks and Literature set-books.

Lack of adequate and necessary training on the aspect of integration was given as the main hindrance to effective and easy implementation of integrated English curriculum. Fifty eight per cent of the teachers (30 teachers) were of this opinion. One teacher argued:

Some teachers are not trained to teach both English language and Literature but they are expected to teach integrated English curriculum. These teachers find it difficult to teach some areas of the syllabus where they are not competent. These teachers require regular guidance on how to approach integrated English curriculum. Unfortunately, KIE and other experts have not given adequate training on integration. Equally, schools have not provided teachers with enough sponsorship to undertake in-service courses on the aspect of integration. Competent facilitators are also rare to come by.

Eighty five per cent of the head teachers (17 head teachers) also pointed out that their teachers of integrated English found it difficult to implement the curriculum because they lacked appropriate training. A head teacher explained:

Most of our teachers were not trained on how to integrate English language and Literature while in their respective colleges, and even some of them took either English language or Literature. Unfortunately, many current practicing teachers have not attended seminars and workshops to prepare for the challenges of implementing integrated English. Thus, the approach confuses them and their learners. In most cases, they handle the various aspects of integrated English independent of each other, ignoring the 
recommended integrated approach.

It is unfortunate that most of the teachers of integrated English had not been trained on how to integrate the two disciplines and their respective constituent parts and yet, according to Thomas [4] such an innovation necessitated (partially) new expertise. He says that innovation involves a process of relearning competencies and attitudes by the existing teachers if at all they are to function well in their classrooms.

Forty four per cent of the teachers (23 teachers) gave limited time allocated to integrated English curriculum as the reason for finding it difficult to implement the program as expected. One of them said:

Time allocated to integrated English on the time-table is inadequate. More time is needed to achieve objectives of integrated English, some of which are unclear to us teachers. The objectives of the two subjects are different and thus difficult to meet within the allocated time.

Fifty five per cent of the head teachers (11 head teachers) were in support of the teachers that time allocated to integrated English is not adequate to teach as expected effectively. One head teacher said:

The time allocated for integrated English on the time-table is too short for the teachers to cover the two disciplines in an integrated manner. In fact, the syllabus is too wide to be covered within the designated time. This is particularly so given that Literature has a lot of work to be done.

Time requires major consideration when implementing a new curriculum. In fact, it takes a lot time for teachers to understand an innovation and to change their practices accordingly, because they will need time to discuss, experiment and learn together so as to gradually acquire key competencies as regards the new curriculum. The teachers will also need time to plan, discuss, reflect and support each other in the implementation of the new curriculum. They cannot just be expected to make instant changes in knowledge, teaching approaches, and attitudes (New Zealand Ministry of Education) [5].

It also came out from the teachers' views (31 of them) that since the mode of setting examinations still requires that teachers teach both English language and Literature in details, the workload is overwhelming on the part of the teachers. This is more so due to the fact that a teacher has to make reference to both the two subjects every now and again.

The results of studies on curriculum implementation in Hong Kong by Carless [6] and [7] confirm the finding of this study that several factors influence implementation of any curriculum innovation. These factors include: adequate and necessary teacher training and support, teacher understanding of an innovation, and the syllabus, time available and availability of resources.

Unlike in the current study where most of the teachers and majority of the head teachers did not embrace integrated English curriculum, almost all staff in Rolfe's [8] study on curriculum innovation in Jersey on the transfer of children from primary to secondary schools, embraced the program and were enthusiastic about taking part in it. Unlike in the case of integrated English, teachers saw the innovation as a necessary change and looked forward to teaching outside their specialisation.

\section{ii) Teachers' Attitudes towards Secondary Integrated English Curriculum}

Individual teachers' attitudes towards change itself and towards the specific innovation intended is an important factor that can contribute to the quality and direction of the change (Altrichter) [9]. Teachers' attitudes towards secondary integrated English are captured in Table below.

Table 2. Teachers' Attitudes towards Secondary Integrated English Curriculum

\begin{tabular}{|c|c|c|c|c|c|c|c|c|c|c|c|c|}
\hline & \multicolumn{2}{|c|}{ Strongly agree } & \multicolumn{2}{|c|}{ Agree } & \multicolumn{2}{|c|}{ Uncertain } & \multicolumn{2}{|c|}{ Disagree } & \multicolumn{2}{|c|}{$\begin{array}{l}\text { Strongly } \\
\text { disagree }\end{array}$} & \multicolumn{2}{|c|}{ Total } \\
\hline & Count & $\%$ & Count & $\%$ & Count & $\%$ & Count & $\%$ & Count & $\%$ & Count & $\%$ \\
\hline $\begin{array}{l}\text { Content of secondary *IEC } \\
\text { is beneficial to the learners } \\
\text { and their teachers. }\end{array}$ & 13 & 13.1 & 56 & 56.6 & 4 & 4.0 & 17 & 17.2 & 9 & 9.1 & 99 & 100 \\
\hline Secondary IEC is broad. & 44 & 44.4 & 39 & 39.4 & 1 & 1.0 & 13 & 13.1 & 2 & 2.0 & 99 & 100 \\
\hline $\begin{array}{l}\text { Secondary *IEC is easy to } \\
\text { teach. }\end{array}$ & 7 & 7.1 & 32 & 32.3 & 11 & 11.1 & 35 & 35.4 & 14 & 14.1 & 99 & 100 \\
\hline $\begin{array}{l}\text { Integration of English } \\
\text { language and Literature has } \\
\text { led to better performance }\end{array}$ & 8 & 8.2 & 27 & 27.6 & 16 & 16.3 & 28 & 28.6 & 19 & 19.4 & 98 & 100 \\
\hline $\begin{array}{c}\text { English language and } \\
\text { Literature should continue } \\
\text { to be taught in an integrated } \\
\text { manner. }\end{array}$ & 13 & 13.1 & 28 & 28.3 & 3 & 3.0 & 30 & 30.3 & 25 & 25.3 & 99 & 100 \\
\hline $\begin{array}{l}\text { English language and } \\
\text { Literature should continue } \\
\text { to be evaluated in an } \\
\text { integrated manner. }\end{array}$ & 13 & 13.1 & 27 & 27.3 & 3 & 3.0 & 30 & 30.3 & 26 & 26.3 & 99 & 100 \\
\hline
\end{tabular}

* IEC- Integrated English Curriculum 
Table 2 shows that $70 \%$ of the teachers (69 teachers) indicated that they either strongly agreed or agreed that the content of secondary integrated English curriculum is beneficial to the learners and their teachers. Only 26 per cent of the teachers (26 teachers) indicating that they either strongly disagreed or disagreed with the statement. From the interviews that were conducted, it was realized that $75 \%$ of the head teachers (15 head teachers) strongly agreed or agreed that the content of secondary integrated English curriculum is beneficial to the learners and their teachers. Two of them said that they were not certain whether it was beneficial to the learners or not. Those head teachers who either strongly disagreed or disagreed that the content of integrated English was beneficial to the learners were $15 \%$ ( 3 head teachers). Thus, a majority of both the teachers and their head teachers were in agreement that the content of integrated English was beneficial to the learners.

Regarding how broad integrated English curriculum is, $84 \%$ of the teachers ( 83 teachers) either strongly agreed or agreed that the curriculum was too broad. Equally, $90 \%$ of the head teachers (18 head teachers) were of the same view that the curriculum was too broad. Whereas $15 \%$ of teachers (15 teachers) felt that the curriculum was not too broad, only one per cent of the head teachers (one head teacher) was of the same view. One teacher and head teacher respectively were uncertain whether the curriculum was too broad or not. Therefore, most teachers and head teachers felt that integrated English curriculum was too broad.

On the item on whether secondary integrated English was easy to teach, $39 \%$ of the teachers (39 teachers) either strongly agreed or agreed. However, $61 \%$ of the teachers $(60$ teachers) either strongly disagreed or disagreed or were uncertain whether it was easy to teach integrated English curriculum or not. Only $35 \%$ of the head teachers (seven head teachers) said that integrated English was easy to teach. Forty five per cent of them (11 head teachers) said that the subject was not easy to teach. Two per cent of the head teachers were not certain whether the curriculum was easy to teach or not. The implication here is that most of the teachers and the head teachers found integrated English curriculum hard to teach.

Forty eight per cent of the teachers (47 teachers) and $45 \%$ of the head teachers ( 9 head teachers) respectively indicated that integration of English language and Literature had not led to better performance. Thirty six per cent of the teachers ( 35 teachers) and $35 \%$ of the head teachers ( 7 head teachers) respectively strongly agreed or agreed that the curriculum had led to better performance. Another 16 per cent of the teachers (16 teachers) and $20 \%$ of the head teachers (4 head teachers) respectively indicated that they were uncertain whether integration had led to better performance. Thus, a majority of the teachers and most of the head teachers did not find any direct link, or were not sure of any, between integration of English language and Literature and performance.

Regarding whether English language and Literature should continue to be taught in an integrated manner, $56 \%$ of the teachers (55 teachers) and $50 \%$ of the head teachers (10 head teachers) respectively strongly disagreed or disagreed. Three per cent of the teachers (three teachers) were uncertain whether integration should continue or not.

Forty one per cent of the teachers (41 teachers) and $50 \%$ of the head teachers (10 head teachers) strongly agreed or agreed that the two subjects should continue to be taught in an integrated manner. The fact that more than half of the teachers and half of the head teachers were against the continued teaching of English language and Literature in an integrated manner raises a lot of concern. In fact, it can be possible that the concept of integration was challenging to both the teachers and schools to effectively put into practice.

Fifty seven per cent of the teachers (56 teachers) and $55 \%$ of the head teachers (11 head teachers) strongly disagreed or disagreed when they were asked whether English language and Literature should continue to be evaluated in an integrated manner. On the other hand, $41 \%$ of the teachers ( 40 teachers) and $45 \%$ of the head teachers ( 9 head teachers) supported the idea of continuing to evaluate English language and Literature in an integrated manner. Three per cent of the teachers (three teachers) were uncertain whether evaluation of English language and Literature in an integrated manner should continue or not. Since most teachers and head teachers were against evaluating the two subjects in an integrated manner, this meant that there was a problem in the manner in which teachers taught and evaluated integrated English.

The findings of this study agree with those of Carless [6]) who did a study on curriculum implementation in Hong Kong and found that teacher beliefs and attitudes strongly influence implementation of curriculum innovation.

\section{iii) Need to Integrate English Language and Literature}

Results on the need to integrate English language and Literature are captured in Table 3.

Table 3. Need to Integrate English Language and Literature

\begin{tabular}{|c|c|c|c|c|}
\hline \multirow{2}{*}{ Response } & \multicolumn{2}{|c|}{ Head Teachers } & \multicolumn{3}{|c|}{ Teachers } \\
\cline { 2 - 5 } & Frequency & Per cent & Frequency & Per cent \\
\hline There is need to integrate the two subjects. & 9 & 45.0 & 48 & 47.5 \\
\hline There is no need to integrate the two subjects. & 11 & 55.0 & 53 & 52.5 \\
\hline Total & 20 & 100.0 & 101 & 100.0 \\
\hline
\end{tabular}


Table 3 shows that $48 \%$ of the teachers (48 teachers) pointed out that there was need to integrate English language and Literature. Equally, $8 \%$ of the head teachers (eight head teachers) said that the move was necessary.

One of the teachers who supported integration of the two subjects argued:

Integration has made the teaching of English language more pragmatic. Literature has given variety to English language teaching and learning. It also has exposed students to a variety of language use in different and several contexts. Actually, integration has enabled students to read widely and to equip themselves with a lot of knowledge. Particularly, borrowing of language from Literature and vice versa has enhanced the learners' level of competence.

On the other hand, a head teacher who was in support of the integration explained:

There was need to integrate English language and Literature because some of the study skills had been neglected in the former syllabus. In the integrated system, all the four language skills, i.e. reading, writing, speaking and listening are incorporated and taken care of. Hence, the learners will now be able to internalize and express themselves better in English language.

Another head teacher supported integration as follows:

Integration of English language and Literature saves learners' time as well as teachers' time because most skills are taught together since the two disciplines have a strong corelationship. This is a better approach that exposes learners and teachers to both fields of English language and Literature. In a way, artistic skills used and taught in literature enhance the learners' language. The approach also helps learners to think broadly and critically through the teaching and analysis of literary texts. Through the teaching and learning of Literature, learners are able to develop and form their own desired characters.

All the same, $53 \%$ of the teachers (53 teachers) and $55 \%$ of the head teachers (11 head teachers) indicated that there was no need for such an action. It can be noted that slightly more than half of the teachers and head teachers did not welcome the idea of integrating the two subjects. Teachers and their head teachers gave a variety of reasons as to why they felt that it was not useful to integrate the two subjects.

Forty one per cent of the teachers (41 teachers) who responded to this item felt that it was not useful to integrate English language and Literature because the two subjects are quite broad to be taught as one unit within the time that is allocated. A teacher said:

The time given to teach integrated English is not enough to cover the syllabus, leave alone to explore the two subjects in detail. In fact, literature is a broad discipline that needs its own special time. Equally,
English language is too broad to be integrated with Literature. Due to lack of adequate time, the holistic approach to Literature is suppressed. It will be in order if English language and Literature can once again be allocated separate times on the time-table and taught as separate entities.

Thirty five per cent of the teachers (35 teachers) said that with integration, Literature as a subject had lost glory and flavour. This is because literature is now being taught as part of English language. It no longer stands out as a distinct subject. One concerned teacher argued:

Literature is now not taught exhaustively and analytically as is expected. Critical thinking and deep analysis of Literature materials and texts has lost meaning since it is English language that is given prominence. Literature is no longer adequately covered. It no longer caters for highly analytical minds. This negates the value of Literature since the objectives of Literature are not met. With integration, our Literature will be forgotten. Literature is interesting when taught as distinct and separate subject.

It was pointed out by another teacher that integration had greatly disadvantaged learners who like Literature since the subject is now taught in a shallow manner. He said:

Integration has killed Literature. Students only learn half Literature and half English language. Each subject should be taught as its own discipline. Both need to be developed on their own to avoid ending up with half-baked learners in both the two subjects.

Twenty nine per cent of the teachers (29 teachers) said that English language and Literature are two distinct disciplines and therefore, each should be taught as its own separate entity.

One of these teachers said:

English language and Literature should be taught separately to avoid biases of the teachers affecting one of the subjects or both. Biases arise from the fact that some of the teachers were only trained in one of the subjects during their pre-service. In some colleges, while being trained, there was the aspect of minor and major subject between English language and Literature. This means that not both were given equal attention. For some teachers, they did not learn both English language and Literature while in college. For those who learnt both, most of them were not trained on how to integrate the two subjects.

It was pointed out by another teacher that when a teacher is not trained in a given subject, he/she finds it difficult to develop an interest in that discipline. Eventually, this leads to lack of competence. She said:

Some teachers are comfortable teaching English language while others are comfortable teaching Literature. Therefore, there is a tendency for teachers 
to over-teach certain skills in English language or Literature, ignoring the rest, depending on the competence of the teacher.

A head teacher who was against integration of English and Literature said:

I do not think there was a desperate need to integrate English language and Literature since the teaching and evaluation became more complicated. I am convinced that English language needs to be taught separately from Literature in English. This way, students will be able to make a choice between the two subjects. As it is today, they do not have any choice and those who do not like Literature find it a burden. Some of the areas in the current syllabus are too difficult for a majority of the students. For instance, they find poetry and the many short stories that they are supposed to read and master to be quite challenging. Learners sometimes get confused. Also, some teachers spend more time on one of the disciplines, depending on their personal interests and specializations, at the expense of the other.

Another head teacher pointed out:

It was not important to integrate English language and Literature. This is because some students are better in English language while others are better in Literature. Integrating both would then mean that learners will not be able to clearly choose the discipline to study and to later specialize in during their further studies. Teachers also have different specializations. Most of them have specialized in either of the two subjects. Thus, integrating the subjects means that most teachers may not deliver as expected.

In an interview with one of the head teachers, it came out that most of the teachers went through pre-service training where English language and Literature were treated as separate entities. It was also pointed out by this head teacher that the integrated English curriculum is too wide to be completed within the allocated time. According to her, this affects revision for examinations.

Other reasons that teachers advanced for being against integration of English language and Literature include: Literature takes most of the time for English language lessons, thus ignoring English language - an important area of the syllabus; no prior training had been given to teachers; both English language and Literature are subjects with their own rules; integrated English confuses and is cumbersome to the learners; one does not have to know Literature to do English language and vice versa; not all learners can study and interpret literature; integration does not allow for proper testing of the skills taught in English language; students are denied a choice between the two subjects and yet some of them are good in English language but not in Literature and vice versa; and examining integrated English is difficult.

\section{iv) Integrated English Curriculum and Learners' Needs}

Table 4 gives information (as given by the teachers of English) on whether integrated English curriculum meets the learners' needs.

Table 4 shows that whereas $52.5 \%$ of the teachers (53 teachers) indicated that secondary integrated English curriculum met the needs of their learners; another $47.5 \%$ of the teachers (48 teachers) said that the curriculum did not meet the needs of their learners. On the item as to whether secondary integrated English curriculum meets the needs of their learners, $60 \%$ of the head teachers (12 head teachers) felt that secondary integrated English curriculum met the needs of their learners while another $40 \%$ of the head teachers (eight head teachers) indicated that it did not.

One of the few head teachers who said that integrated English curriculum met the needs of their learners pointed out:

There is now a practical element in the teaching and use of language. The passive approach of teaching English language on its own is no longer applicable. The integrated approach has made teaching and learning of English language both enjoyable and stimulating. The learners get exposed to almost all aspects of English language and Literature and this equips them with the necessary pre-requisite ingredients for future endeavours, and better language results and competence. The approach has enabled the learners to appreciate the close connection between English language and Literature.

In an interview with a head teacher who argued that integrated English curriculum did not meet the needs of the learners, it was realized that due to the time constraint, learners were under too much pressure to complete the syllabus. As a result, integrated approach is not widely used by the teachers and their learners. This head teacher added:

With most of the teachers being unfamiliar with integration, the results are anybody's guess.

Table 4. Integrated English Curriculum versus Learners' Needs

\begin{tabular}{|c|c|c|c|c|}
\hline \multirow{2}{*}{ Response } & \multicolumn{2}{|c|}{ Head Teachers } & \multicolumn{3}{c|}{ Teachers } \\
\cline { 2 - 6 } & Frequency & Per cent & Frequency & Per cent \\
\hline Integrated English curriculum meets learners' needs. & 12 & 60.0 & 53 & 52.5 \\
\hline Integrated English curriculum does not meet learners' needs. & 8 & 40.0 & 48 & 47.5 \\
\hline Total & 20 & 100.0 & 101 & 100.0 \\
\hline
\end{tabular}


Another head teacher who was of the view that the curriculum did not meet the needs of the learners said:

\section{I think that integration narrows learners to studying only a few set-books. To the contrary, they are supposed to read a lot of literary materials more than just a few set-books so as to be ready to handle Literature at higher levels. The approach confuses the learners when all the aspects of English language and Literature are taught together as one subject-English. This confusion contributes to mass failure especially for the weak students.}

One of the head teachers argued that performance in Kiswahili which is not fully integrated seems to be much better compared to the performance in English. She further pointed out that integration goes against the spirit of student specialization, that is, choosing to study one subject deeply with a hope of pursuing that discipline to greater heights later in the course of his/her studies.

All the same, $50 \%$ of the teachers (50 teachers) and $30 \%$ of the head teachers (six head teachers) said that their learners liked the integration of English language and Literature. One of the teachers said:

The learners have no choice. In the first place, they were not given room to compare and decide whether to do English language or Literature as separate subjects. They, therefore, have to like integrated English curriculum the way it is so as to pass their examinations. If anything, the practical approach that is employed to teach integrated English is much more interesting and interactive.

During the interviews, another head teacher explained:

Learners like integration because the approach provides more time for interactive and learner-based learning. Learners now read and discuss language and use of literary devices in a practical way. They say English language is no longer a subject full of abstract and boring concepts. Hence, they are more active in the learning process than before. They enjoy themselves throughout the integrated English sessions.

Forty four per cent of the teachers (44 teachers) and $70 \%$ of the head teachers (14 head teachers) indicated that their learners did not like integration of the two subjects. One of the teachers explained the students' dislike of integrated English as follows:

Students find integrated English to be too wide, involving and demanding. It demands a lot of their participation and dedication. This disadvantages those students who lack good language command to effectively participate in class. On the same note, those who do not have an aptitude for Literature, find it inaccessible, almost drudgery. Thus, when the two subjects are presented in an integrated manner, the concepts get mixed up and this brings about confusion and lack of clarity of the subject. Comprehension of the subject becomes minimal.

Another teacher said:

With integration, there is no room for enjoyment and creativity that comes with the teaching of Literature as a distinct subject on its own. Extensive reading of Literature as a distinct field is no longer there. The learners do not get enough time to analyse Literature books comprehensively. Consequently, they tend to use the little time allocated to integrated English to learn Literature and thus, ignore English language.

According to another teacher of integrated English:

Integration kills creativity in composition writing since they have to reproduce textual materials. (Composition is nowadays based on literature set text books). Also, students who would like to specialize in one of the two disciplines where they have interest and are good in, are not allowed to do so due to integration. Hence, students post poor results since they are forced to do the two disciplines in an integrated manner.

Majority of the head teachers (14 of them) said that their learners did not like integration of English language and Literature. One of these head teachers argued:

Learners do not like integration of English language and Literature. They claim that the approach is confusing. Most of them are not able to integrate the two subjects in the learning situations. For example, they are not able to connect Literature and grammar. Despite this situation, the current syllabus demands that learners should be able to learn aspects of grammar, writing skills, sentence structures and even vocabulary from the Literature set-books. Unfortunately, most students still view the two subjects as two separate entities and tend to enjoy approaching each separately. Consequently, in answering questions and/or compositions based on set-books, students ignore the grammatical structures and concentrate on required number of points. Examiners deny such students full marks despite their having the required points.

It was also clear from another head teacher that learners did not like integration. In an interview with him, he said:

Pressure to complete the wide integrated English syllabus has made the subject less interesting to the learners. The content they are expected to master is simply too wide within the allocated time. As a result, teachers just force their students to write many notes which they do not even read. Also, the learners find it a bother to apply knowledge of literature in English language and vice versa. Some of them like English language while others like Literature. Those who like literature do, whereas those who do not, do not. Those 
who do not like Literature find it cumbersome and even complain about it. But those who like Literature rely on it to do well in English. If the two subjects are separated, the learners would make more relevant choices based on their interests.

Whereas in 27 of the lessons that were observed by the researcher learners actively participated and were enthusiastic about the learning of integrated English, in the other 53 lessons that were observed, the learners were dull and disinterested with the subject and/or the learning process. They rarely participated in the learning process. This scenario is a likely pointer that the learners' needs and interests might have not been met by the content of integrated English in most of the lessons.

\section{v) Objectives of Secondary Integrated Curriculum}

The researcher sought to know teachers' reactions as regards significance of clarity of objectives of secondary integrated English curriculum and their own clarity regarding the same objectives. Their respective reactions are captured in Tables 5 and 6 .

Approximately $85 \%$ of the teachers and $65 \%$ of the head teachers (13 head teachers) (see Table 5) said that clarity of objectives of secondary integrated English curriculum was significant. On the other hand, $14.9 \%$ of the teachers $(15$ teachers) and $35 \%$ of the head teachers (seven head teachers) (see Table 5) indicated that clarity of the objectives was not significant. It is clear that both teachers and head teachers appreciate the significance of clarity of the objectives of integrated English curriculum. This finding is in tandem with Fullan's [10] assertion that lack of conceptual clarity can frustrate curriculum implementation.

On whether the objectives of secondary integrated English curriculum were clear to them, $59.4 \%$ of the teachers and $55 \%$ of the head teachers (11 head teachers) (see Table 6) said that the objectives were clear to them while $40.6 \%$ of the teachers and $45 \%$ of the head teachers (nine head teachers) (see Table 6) said the objectives were not clear to them. This is a sad situation since lack of role clarity and ambiguity about expectations can frustrate implementation of the innovation [10].

Nine of the interviewed head teachers argued that they were not teachers of integrated English and therefore, they were not expected to have a clear understanding of the objectives of the subject. If anything, they pointed out, the new curriculum was imposed on the majority of the stakeholders. In other words, they felt that teachers of integrated English and other stakeholders were not actively involved right from the inception stage of the curriculum for them to understand it and its objectives properly.

Although more than half of the teachers (60 teachers) and head teachers (11 head teachers) had indicated that they were clear on the objectives of integrated English, only $21 \%$ of the teachers (12 teachers) and $10 \%$ of the head teachers (two head teachers) were able to state at least five objectives of the course.

Table 5. Significance of Clarity of Objectives of Secondary Integrated English Curriculum

\begin{tabular}{|c|c|c|c|c|}
\hline \multirow{2}{*}{ Response } & \multicolumn{2}{|c|}{ Head Teachers } & \multicolumn{2}{|c|}{ Teachers } \\
\cline { 2 - 5 } & Frequency & Percent & Frequency & Percent \\
\hline Clarity of the objectives of integrated English curriculum is significant. & 13 & 65.0 & 86 & 85.1 \\
\hline Clarity of the objectives of integrated English curriculum is not significant. & 7 & 35.0 & 15 & 14.9 \\
\hline Total & 20 & 100.0 & 101 & 100.0 \\
\hline
\end{tabular}

Table 6. Clarity of Objectives of Secondary Integrated English Curriculum to Teachers

\begin{tabular}{|c|c|c|c|c|}
\hline \multirow{2}{*}{ Response } & \multicolumn{2}{|c|}{ Head Teachers } & \multicolumn{2}{|c|}{ Teachers } \\
\cline { 2 - 5 } & Frequency & Per cent & Frequency & Per cent \\
\hline Objectives are clear. & 11 & 55.0 & 60 & 59.4 \\
\hline Objectives are not clear. & 9 & 45.0 & 41 & 40.6 \\
\hline Total & 20 & 100.0 & 101 & 100.0 \\
\hline
\end{tabular}




\section{Summary of Study Findings}

The following is a summary of the findings:

1. A substantial number of teachers faced difficulties when implementing integrated English curriculum. Eighty per cent of the lessons observed (64 classroom lesson observations) showed that the concerned teachers taught English language and Literature as separate subjects. They did not exploit the complementary relationship between the two subjects to teach the integrated English curriculum.

2. A majority of the teachers and their head teachers were in agreement that the content of integrated English was beneficial to the learners.

3. Most of the teachers and head teachers felt that integrated English curriculum was too broad.

4. Most of the teachers and the head teachers found integrated English curriculum hard to teach.

5. A majority of the teachers and most of the head teachers did not find any direct link, or were not sure of any, between integration of English language and Literature and performance.

6. More than half of the teachers and half of the head teachers were against continued teaching of English language and Literature in an integrated manner.

7. Most teachers and head teachers were against evaluating the two subjects in an integrated manner.

8. Slightly above half of the teachers and their head teachers indicated that secondary integrated English curriculum met the needs of their learners.

\section{Recommendations of the Study}

The following are the recommendations of the study:

1. The MoE should help teachers and other implementers acquire and develop necessary content, knowledge and pedagogical skills as regards the concept of integration and in particular the teaching of integrated English curriculum.

2. The MoE should facilitate implementation of integrated English curriculum by sending to schools guiding policies on how to effectively teach integrated English, and ensuring that there are adequate teachers for integrated English in schools (through its specialized agency, TSC).

3. The MoE field officers should carry out regular classroom teaching supervisions and advise teachers accordingly.

4. KIE should review integrated English syllabus and address most of the implementers' needs, interests, fears and problems as regards the subject

5. KIE should conduct regular seminars, workshops and conferences for the teachers of integrated English curriculum. During these seminars, workshops and conferences, content and pedagogical issues should be handled by the experts. This will bridge the gap between pre-service training of the teachers and the reality in the schools in terms of the teaching of the integrated English curriculum.

6. KIE should allocate more official lesson time to integrated English curriculum so as to enable teachers have enough time to teach as per the demands of the subject - eight lessons per week for Forms One and Two, and 10 lessons per week for Forms Three and Four.

7. KIE should have adequate and well trained curriculum specialists and resources for the Institute to be able to effectively carry out its mandate of training teachers on the implementation of integrated English curriculum.

8. Given the central position that KNEC occupies in the implementation of integrated English curriculum, it should aggressively carry out seminars, workshops and conferences for most of the teachers, if not all, on how to teach and evaluate English language and Literature in an integrated manner.

9. KNEC should also facilitate teachers in their implementation of the integrated English curriculum by:

- Providing examination sample papers to guide teachers in their daily endeavours

- Providing teachers with syllabuses which they can follow in carrying out their teaching of integrated English

- Providing teachers with reports on KCSE results.

10. Pre-service training of teachers in universities and colleges should be reformed and integrated English approach adopted. This way, teachers to-be will be familiarized with the integrated approach and their competence in handling integration developed.

11. Practicing teachers and head teachers should undergo proper in-service training as regards the purpose and objectives, and the teaching and evaluation and/or supervision of integrated English curriculum.

12. Schools should provide adequate teaching and learning resources should be provided to teachers such that they can teach and evaluate integrated English as expected.

\section{REFERENCES}

[1] Altrichter, H. (2005). Curriculum implementation - limiting and facilitating factors. Retrieved January, 2011, from http://www.kreativinnovativ09

[2] Kenya Institute of Education (2002). Secondary Education Teacher Preparation Guide for English. Nairobi: KIE.

[3] Ministry of Education (2006). Secondary English Teacher's Handbook. Nairobi: Kenya Institute of Education. 
[4] Kenya National Examinations Council (2006). 'Radical Changes as K.C.S.E. Exams Begin' in the Daily Nation, Nairobi: Nation Media Group.

[5] Thomas, R. M. (1994). Implementation of educational reforms. In: Husen, T. and Postlethwaite, T.N. (eds.): The International Encyclopaedia of Education. $2^{\text {nd }}$ edition. Pergamon: Oxford.

[6] New Zealand Ministry of Education (2010). The time needed for implementation. Retrieved January 25, 2010, fromhttp://nzcurriculum.tki.org.nz

[7] Carless, D. R. (2003). Factors in the implementation of task-based teaching in primary schools. Retrieved November 19, 2009, from http://www.sciencedirect.com.

[8] Carless, D. R. (1999). A Case study of curriculum implementation in Hong Kong. Retrieved November 19, 2009, from http://www.sciencedirect.com.

[9] Rolfe, R. (2009). Curriculum innovation in Jersey. Retrieved November 19, 2009, from http://www.ssat-inet.net.

[10] Fullan, M. (1994). Implementation of Innovations. In: Husen, T. and Postlethwaite, T. N. (eds.): The International Encyclopaedia of Education. 2nd edition. Pergamon: Oxford. 